\title{
Difference in blast development in upland rice grown on an Andosol vs a Ferralsol
}

\author{
Mathilde Sester $^{\mathrm{a}, \mathrm{b}, *}$, Harinjaka Raveloson ${ }^{\mathrm{c}}$, Didier Tharreau ${ }^{\mathrm{d}, \mathrm{e}}$, Thierry Becquer ${ }^{\mathrm{f}}$ \\ ${ }^{\text {a }}$ CIRAD, UPR AIDA, F-34398, Montpellier, France \\ b AIDA, Univ. Montpellier, CIRAD, Montpellier, France \\ c FOFIFA, CRR Trivatrinikamo, B.P. 230, 110 Antsirabe, Madagascar \\ d BGPI, Univ. Montpellier, CIRAD, INRA, Montpellier SupAgro, Montpellier, France \\ e CIRAD, UMR BGPI, F-34398, Montpellier, France \\ ${ }^{\mathrm{f}}$ Eco\&Sols, IRD, CIRAD, INRA, Montpellier SupAgro, Univ. Montpellier, Montpellier, France
}

\section{A R T I C L E I N F O}

\section{Keywords:}

Magnaporthe oryzae

Rice blast

Soil characteristics

Agronomic management

\begin{abstract}
A B S T R A C T
In the densely populated highlands of Madagascar, growing upland rice offers the opportunity to increase the total rice cropping area and to improve food security. However, rice blast was a major constraint for the first cultivars released in the 1990s and consequently limited the extension of upland rice. However, blast epidemics are much less intense in the region of Betafo, where the composition of the soil, an Andosol developed from volcanic rock, is different from the classical Ferralsol of the highlands. A 3-year field experiment (2009-2011) was conducted near Antsirabe to compare blast epidemics on rice grown in Ferralsol vs. an Andosol. Leaf and panicle blast development were monitored and the yield components of upland rice plants growing on the two different soil orders were measured. In 2009 and 2011, leaf and panicle blast development were significantly lower for plants grown on the Andosol compared to those grown on the Ferralsol (final panicle blast reduced by $40 \%$ in 2009 and $20 \%$ in 2011). The severity of blast was shown to be related to the concentrations of mineral elements in the plant, and the Si content was significantly higher in plants growing on the Andosol. In 2010, the differences of blast incidence between the two soils were less marked (14\% reduction of panicle blast at the last scoring date). AUDPC were lower in the Andosol compared to the Ferralsol each year, for leaf and panicle blast. The yield components 1000 full grain weight, dry straw weight and the yield were higher in the Andosol compared to the Ferralsol in 2009 and 2010 but were not significantly different in 2011. These results clearly document that blast development may be impacted by the soil order in which rice is grown, and future agronomic management of blast should focus on improved soil mineral composition such as silicon.
\end{abstract}

\section{Introduction}

Blast, caused by the fungus Pyricularia oryzae Cavara [syn. Magnaporthe oryzae Couch ], is one of the most widespread diseases of rice (Oryza sativa L.) and occurs in all rice growing regions in the world (Pennisi, 2010). The damage caused by leaf blast is due to the decrease in active photosynthetic area during the growing stage, which results in a decrease in tillering, in the number of panicles and in the number of grains per panicle (Bastiaans, 1991) and can kill the plants fully in severe situations. In terms of yield loss, panicle or neck blast is the most destructive form of the disease because it prevents grain filling (Ou, 1985).

Rice is the staple food crop in Madagascar with a consumption of $154 \mathrm{~kg}$ per capita per year in 2013 (FAOSTAT, 2018). The country needs to import rice to supply its own production. The traditional rice production in the lowlands is limited by the area that can be devoted to that cropping system. Upland rainfed rice is a recent crop in the densely populated highlands of Madagascar, whose altitude ranges from 1400 to $1800 \mathrm{~m}$ above sea level ( $\mathrm{m}$ asl), making it possible to increase the area under rice production and to improve the food security of farm households. The first cultivars released to farmers during the $1990^{\mathrm{s}}$ were rapidly attacked by blast (Raboin et al., 2014) and the disease continues to be a constraint for any new cultivar developed and released in the region. Today, there is a race between breeders and blast: breeders have to rapidly produce new cultivars and find new sources of resistance, because blast rapidly adapts to any new resistant cultivars and is simultaneously becoming increasingly aggressive. Even the severity of blast on upland rice in farmer's field is low due to the tolerance

\footnotetext{
* Corresponding author. CIRAD, UPR AIDA, F-34398, Montpellier, France.

E-mail address: mathilde.sester@cirad.fr (M. Sester).
} 
of cultivars, blast pressure is still high and caused $50 \%-100 \%$ yield losses over the last 10 years at the experimental research station (Sester et al., 2014). There is thus an urgent need for other strategies to limit blast pressure and to delay the extension of virulent forms of the pathogen, thereby increasing the useful life of the new cultivars.

Blast management strategies usually involve cultivars and fungicide treatments, but this later practice is not sustainable and is too expensive for poor farmers in Madagascar, so agroecological management is necessary to reduce the propagation of the inoculum like crop rotations and residues destruction (Raveloson et al., 2018). Many studies have shown that the nutritional balance can be successfully used to limit blast epidemics, confirming that rice tolerance to blast can be enhanced by improving rice nutrition (Datnoff et al., 2007; Sester et al., 2014; Dusserre et al., 2017).

The soil characteristics (organo-mineral and biological content) are known by agronomists to play a key role in the development of blast epidemics but only a few experiments have demonstrated it at the field level. In 1981, Seguy et al. conducted an experiment to measure the impact of soil on rice susceptibility to blast and compared rice growing on a volcanic vs an hydromorphic soil from Cameroon, in pots placed outside in a place with a high blast pressure. The differences in blast severity they measured were spectacular. After analysis of soil mineral content, they concluded that the "natural fertility potential" of the volcanic soil explained why the level of blast was consistently lower on plants grown on that soil. A similar experiment was reported by Bonman (1992), with pots transferred from one region of the Philippines to another. In conclusion, the authors proposed that the term "disease potential" should be applied to each site depending on the soil type.

In Madagascar, epidemics of blast disease are much less intense in the region of Betafo, an important traditional rice production area located $22 \mathrm{~km}$ west from Antsirabe, which is characterized by Andosols developed on recent volcanic materials, than on the acid Ferralsols in the highlands. Based on those observations, we conducted a 3-year field experiment to compare blast disease in rice grown on a typical Ferralsol and on Andosol imported from the Betafo region, to investigate the ability of plants grown under specific soil fertility to improve their tolerance to blast disease in the field and to identify the relationship between the direct impact of soil on tolerance factors and the indirect impact through plant development. We hypothesized that cropping practices that restore soil fertility will improve rice tolerance to diseases in Ferralsol.

\section{Materials and methods}

\subsection{Location}

The experiment was conducted at Andranomanelatra (S $19^{\circ} 78^{\prime}, \mathrm{E}$ $47^{\circ} 11^{\prime}, 1640 \mathrm{~m}$ asl.) in the Vakinankaratra region of the highlands of Madagascar. The tropical altitude climate is characterized by cool dry winter from May to September and warm wet summer from October to April, which is the rice cropping season. Average annual rainfall is $1460 \mathrm{~mm}$.

\subsection{Plant material}

Two upland rice cultivars adapted for high altitude were used. Fofifa 152 (F152) is one of the first cultivars selected in the CIRADFOFIFA breeding program (Raboin et al., 2013). It was successfully released to farmers in the 1990s and was appreciated for its taste. However, in 2003 this cultivar resistance broke down and is now considered one of the most susceptible cultivars adapted to the rainfed conditions typical of the region. Fofifa 172 (F172) is a recent cultivar, and was seen to be resistant to nine differential strains of $P$. oryzae isolated from upland rice in Madagascar, after inoculation in a greenhouse (data not shown). It was used as a barrier between plots of F152.

\subsection{Soil type}

Two types of soil were compared in this study. The first type of soil, at Andranomanelatra, developed on volcano-lacustrine alluvia (Raunet, 1981). The second soil was transported from the village of Betafo, $18 \mathrm{~km}$ west of Antsirabe, in a region with recent volcanism. The type of soil at Andranomanelatra was classified as Geric Ferralsol according to the FAO soil classification (IUSS Working Group, 2014), using data collected by Razafimbelo et al. (2006). The soil texture is clayey with $66 \%$ clay, $17 \%$ fine silt, $3 \%$ coarse silt, $6 \%$ fine sand and $8 \%$ coarse sand. The soil is acidic (water $\mathrm{pH} 4.6$ ) and the total carbon content is $46.9 \mathrm{~g} \mathrm{~kg}^{-1}$. The soil from Betafo is classified as Silandic Andosol, and contains $12 \%$ clay, $39 \%$ fine silt, $12 \%$ coarse silt, $16 \%$ fine sand and $21 \%$ coarse sand (data from soil analysis performed in 2009).

\subsection{Experimental design}

The experiments were conducted in 2009, 2010 and 2011. The field was plowed manually and a fine seedbed prepared by secondary tillage. Six to eight rice seeds were sown manually in seed holes spaced $20 \times 20 \mathrm{~cm}$ apart $\left(25\right.$ hills per $\mathrm{m}^{2}$ ). Before sowing, rice seeds were treated with Gaucho ${ }^{\circ}$ ( $35 \%$ imidacloprid $+10 \%$ thiram) at a rate of $2.5 \mathrm{~g}$ per kg of seeds, as protection against insects. Weeds were removed by hand. The same amount of fertilizer was applied to each plot: cattle manure at a rate of $5 \mathrm{tha}^{-1}$ fresh weight plus NPK mineral fertilizer $\left(11 \% \mathrm{~N}, 22 \% \mathrm{P}_{2} \mathrm{O}_{5}, 16 \% \mathrm{~K}_{2} \mathrm{O}\right)$ at $300 \mathrm{~kg} \mathrm{ha}^{-1}$, dolomite $\left(\mathrm{CaMg}\left(\mathrm{CO}_{3}\right)_{2}\right)$ at $500 \mathrm{~kg} \mathrm{ha}^{-1}$ applied at sowing and two top-dressings of urea $(46 \% \mathrm{~N})$ at $50 \mathrm{~kg} \mathrm{ha}^{-1}$ applied 30 and 70 days after sowing (beginning of tillering and beginning of the booting stage).

A randomized complete-block design was used for all three experiments with four replicates. Elementary plots containing the susceptible F152 variety $(3 \mathrm{~m} \times 3 \mathrm{~m}$ in 2009 and $2011,3 \mathrm{~m} \times 5 \mathrm{~m}$ in 2010) were separated by $3 \mathrm{~m}$ of F172 to avoid border effects. The basic rotation was two years, with upland rice followed by intercropping with pigeon pea (Cajanus cajan), sunnhemp (Crotalaria grahamiana) and finger millet (Eleusine coracana). Two neighboring fields were cultivated by turns (one in 2009 and 2011, the other in 2010). In 2009, we removed $4 \mathrm{~m}^{3}$ of Andosol from an upland rainfed field, cropped with rice the previous year, in the region of Betafo. The soil sample was placed in a cylindrical hole, $0.50 \mathrm{~m}$ in depth (depth of the major part of the roots, Dusserre et al., 2012) and $1.6 \mathrm{~m}$ in diameter $\left(1 \mathrm{~m}^{3}\right)$, in the center of the elementary plots. In 2010 and 2011, $6 \mathrm{~m}^{3}$ of soil from another field in Betafo were placed it in a rectangular $1.5 \mathrm{~m} \times 2 \mathrm{~m}$ hole, $0.50 \mathrm{~m}$ in depth in the center of the elementary plots.

Three treatments were compared each year: rice growing on the local Ferralsol, rice growing on imported Andosol and, as a control of growth potential rice growing on Ferralsol with chemical treatment against blast: alternate fungicide treatments with Antracol ${ }^{\circ}(70 \%$ Propineb, $3 \mathrm{~kg} \mathrm{ha}^{-1}$ ) and carbendazim (50\% carbendazim, $11 \mathrm{ha}^{-1}$ ) applied once a week in 2009 and twice a week in 2010 and 2011 from the first symptoms observation during tillering to the end of filling stage with a backpack sprayer (Cooper Pegler ${ }^{\circ}$, model CP15).

\section{Measurements}

\subsection{Assessment of blast disease}

Blast infection occurred naturally in our experiments. Leaf blast severity was estimated weekly from the first symptoms observation (in general during the first stage of tillering) to flowering stage (Dusserre et al., 2017), six times in 2009 and 2010 and seven times in 2011. The severity of leaf blast (LB) was assessed as follows: on 10 hills per experimental unit, the total number of tillers per hill and the number of tillers with at least one typical leaf blast symptom were counted; on three diseased tillers, the percentage of leaf area affected by blast symptoms was estimated visually on the four uppermost fully expanded 
leaves. The value of leaf blast severity at the hill scale was then calculated as described in Dusserre et al. (2017):
The samples were sent to the "Laboratoire des radioisotopes, Antananarivo, Madagascar" where $\mathrm{N}$ content, $\mathrm{pH}$, total phosphorus,

Leaf Severity $=$ Mean $\left(\frac{\% \text { of leaf area presenting blast symptoms on diseased tillers } \mathrm{x} \text { number of diseased tillers }}{\text { total number of tillers }}\right)$

The leaf blast severity of an experimental unit is the mean of leaf blast severity of the 10 hills.

Area Under Disease Progress Curve for leaf blast severity (AUDPC $\mathrm{l}_{\mathrm{lb}}$ ) has been calculated for each experimental unit:

$A U D P C_{l b}=\sum_{i=1}^{n}\left[\frac{l s_{i}+l s_{i+1}}{2}\right] *\left[\left(t_{i+1}-t_{i}\right)\right]$

with $1 s_{i}$ the mean leaf blast severity for observation $i, t_{i}$ the number of days after sowing at observation $i$ and $n$ the number of observations of leaf blast in the experimental unit.

After flowering, panicle blast (PB) symptoms were evaluated weekly, five times in 2009, four times in 2010 and seven times in 2011. Healthy and diseased panicles were counted on 10 hills. On five diseased panicles per hill, we visually estimated the percentage of diseased spikelets (i.e. those with a black stem). When the neck nodes were infected by the pathogen, the panicle dries out and turns white (counted as $100 \%$ of spikelets affected). PB severity was obtained by calculating the mean of the severity values for the 10 hills in the experimental unit:
Olsen phosphorus and exchangeable potassium content were analyzed. Chemical analyses of soils were performed on air-dried soil whose particles were less than $2 \mathrm{~mm}$ in size. $\mathrm{pH}$ was measured in soil water and in $1 \mathrm{M} \mathrm{KCl}$ suspensions using 1:2.5 (w:v) soil:solution ratio. Total organic carbon (C) was determined with the Walkley-Black dichromate oxidation method and total nitrogen $(\mathrm{N})$ with the Kjeldahl method. Exchangeable $\mathrm{K}^{+}$was extracted with cobalt hexamine chloride and determined by atomic absorption spectrometry. Total $\mathrm{P}$ was determined after perchloric acid $\left(\mathrm{HClO}_{4}\right)$ digestion. Olsen-extractable $\mathrm{P}$ was obtained after extraction with $0.5 \mathrm{~N}$ sodium bicarbonate solution ( $\mathrm{pH}$ 8.5). The $\mathrm{P}$ in the soil extracts was determined using the blue molybdate-ascorbic acid method.

In 2011, the pseudo-total $\mathrm{SiO}_{2}$ content $\left(\mathrm{Si}_{\text {total }}\right)$ was estimated for each plot (4 blocks for each soil origin) after dissolution in 1:1 conc. $\mathrm{H}_{2} \mathrm{SO}_{4}$. This method is considered as a pseudo-total because the extraction is thought to attack primarily amorphous and poorly ordered silica as well as fine-grained crystalline clays, but not the most resistant silicate minerals, which are mainly quartz. The available Si pool was quantified using an extraction with $0.2 \mathrm{moll}^{-1}$ ammonium oxalate-

Panicle Blast Severity $=$ Mean $\left(\frac{\% \text { of diseased spikelets on diseased panicles } \mathrm{x} \text { number of diseased panicles }}{\text { total number of panicles }}\right)$

Area Under Disease Progress Curve for panicle blast severity $\left(\mathrm{AUDPC}_{\mathrm{pb}}\right.$ ) has been calculated for each experimental unit:

$A U D P C_{p b}=\sum_{i=1}^{n}\left[\frac{p s_{i}+p s_{i+1}}{2}\right] *\left[\left(t_{i+1}-t_{i}\right)\right]$

with $\mathrm{ps}_{\mathrm{i}}$ the panicle severity for observation $\mathrm{i}, \mathrm{t}_{\mathrm{i}}$ the number of days after sowing at observation $i$ and $n$ the number of observations of panicle blast in the experimental unit.

\subsection{Grain yield and yield components}

Grain yield (using unhulled seeds), yield components, and straw dry weight were measured at maturity. The number of plants, panicles, and spikelets per panicle, the number of filled and unfilled spikelets, 1000grain weight and grain and straw yields were measured on eight hills located in the center of each experimental unit. All plant samples were separated into straw and panicles. The panicles were counted and hand threshed, and the filled and unfilled spikelets were separated. The dry weight of filled spikelets and unfilled spikelets was determined after oven drying at $60^{\circ} \mathrm{C}$ for three days. Sub-samples comprising 200 filled spikelets and 200 unfilled spikelets were weighed to calculate the total number of filled and unfilled spikelets and 1000-grain weight. The fertility was calculated as the percentage of grain filling (100 x number of filled spikelets/total number of spikelets). Grain yield and straw dry weight were determined after drying at $60^{\circ} \mathrm{C}$ for three days.

\subsection{Soil and plant mineral analyses}

In 2009, we analyzed three samples of soil taken from the local field before the rice was sown and three samples of the imported soil. oxalic acid at $\mathrm{pH} 3$, which extracts $\mathrm{Si}$ bound to poorly crystalline components (allophane and imogolite) and weakly ordered sesquioxides (Cornelis et al., 2011).

At the flowering stage, 30 flag leaves of rice plants not used for yield parameters were sampled from the Ferralsol and Andosol, for leaf analysis at the CIRAD water, soil, plant analyzes laboratory in Montpellier, France, in 2009 and 2011. After the leaves were dried at $60{ }^{\circ} \mathrm{C}$ for $48 \mathrm{~h}$, total leaf $\mathrm{N}$ was determined with the Dumas combustion method using a 'Leco N-analyzer' (FP528-LECO). Foliar P, K, Ca, Mg, $\mathrm{Na}, \mathrm{Cu}, \mathrm{Mn}, \mathrm{Zn}$ and $\mathrm{B}$ were analyzed by ICP. The amount of $\mathrm{SiO}_{2}$ in the flag leaves was measured by gravimetry with the method used by Horwitz (1960) and is reported as the \% of SiO2 in the dry matter, S was analyzed by turbidimetry.

\subsection{Statistical analysis}

Statistical analyses were performed with the Statistical Analysis System (SAS) v.9.2 (SAS Institute Inc., Cary, NC). Means and standard errors were generated with PROC MEANS. Disease severity values were transformed using the Arcsin of the square root transformation. The MIXED procedure (with Random statement) was used for analysis of variance. LSD test was used for mean separation. ANOVA was used to compare leaf and panicle AUDPC, and soil and leaf mineral contents in Ferralsol vs Andosol.

\section{Results}

\subsection{Blast measurements}

Dynamics of leaf and panicle blast were measured throughout the 3year experiment (Fig. 1). The difference of leaf blast between soils was significant $(P<0.05)$ after the second measurement date in 2009 and 


\section{A : 2009}

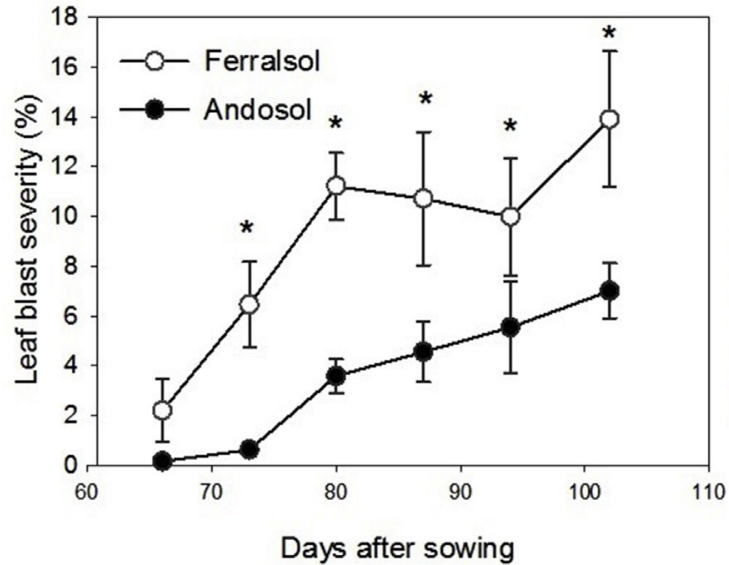

\section{B : 2010}

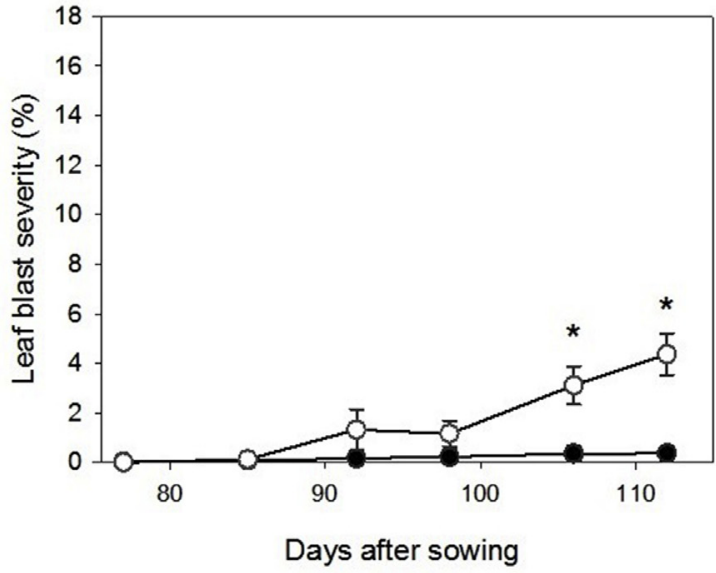

\section{C : 2011}

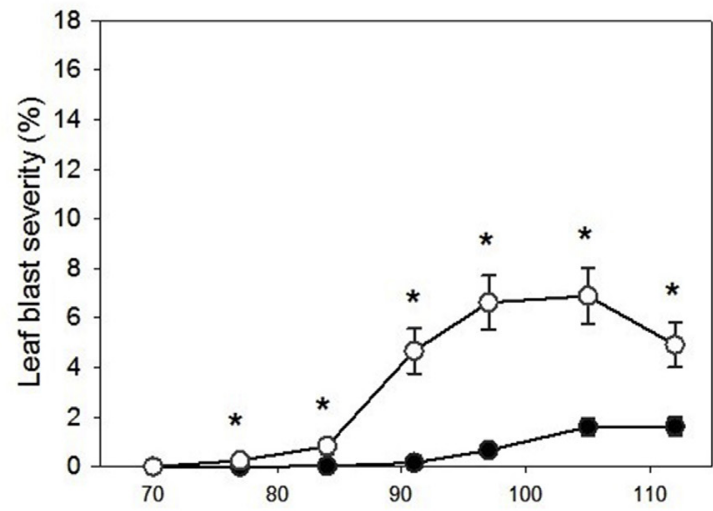

Days after sowing

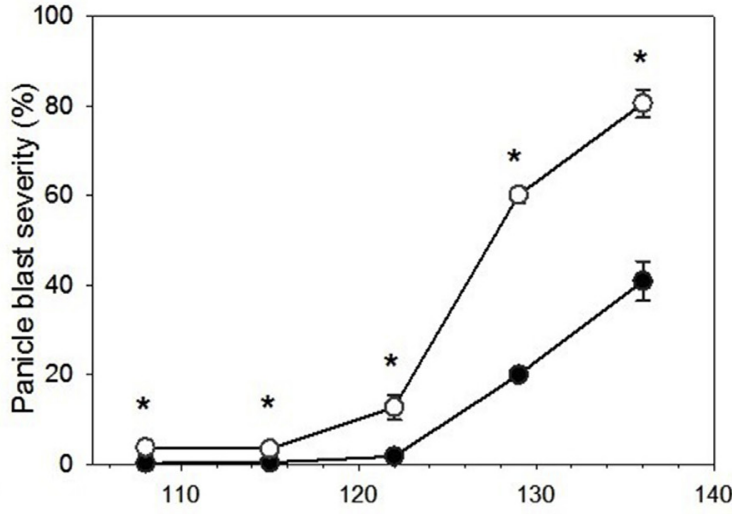

Days after sowing
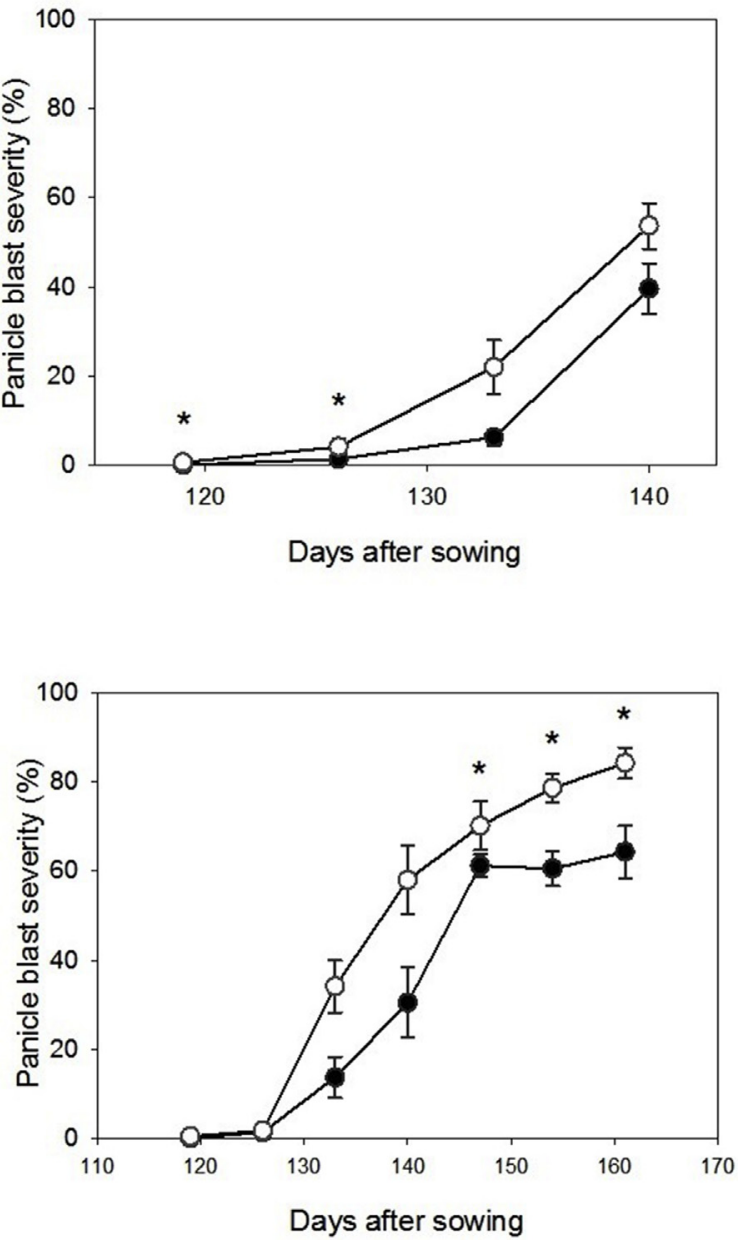

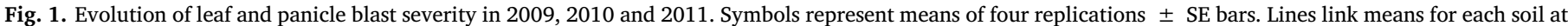

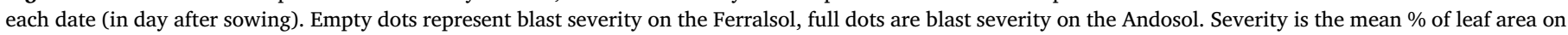

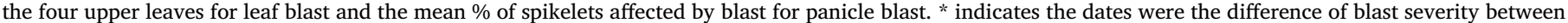
the two soils was significant $(\mathrm{P}<0.05)$.

2011, and after the fifth measurement date in 2010. Leaf blast (LB) severity increased during the development of the crop each year for both soils, but was always more severe on plants grown on the Ferralsol than on the Andosol (Fig. 1A, B and 1C) and particularly at the last scoring date: $13.9 \%$ vs. $7.0 \%$ in $2009,4.4 \%$ vs. $0.4 \%$ in 2010 , and $4.9 \%$ vs. $1.6 \%$ in 2011 . AUDPC for leaf blast were always significantly different between the two soil orders $(P<0.05$, Table 1$)$.

The effect of soil on panicle blast (PB) was also highly significant on all measurement dates in each year except at the end of the 2010 season and on the four first dates in 2011 (Fig. 1, Table 1). Panicle blast 
Table 1

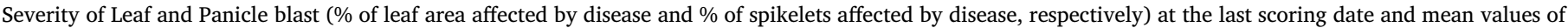
AUDPC (\%.day), each year in each soil. Values followed by an asterisk differed significantly between soil (P < 0.05 ).

\begin{tabular}{|c|c|c|c|c|c|}
\hline \multirow[t]{2}{*}{ Year } & \multirow[t]{2}{*}{ Soil } & \multicolumn{2}{|l|}{ Leaf Blast } & \multicolumn{2}{|l|}{ Panicle Blast } \\
\hline & & $\begin{array}{l}\text { Severity at the last } \\
\text { scoring date (\%) }\end{array}$ & AUDPC (\%.day) & $\begin{array}{l}\text { Severity at the last } \\
\text { scoring date (\%) }\end{array}$ & AUDPC (\%.day) \\
\hline \multirow[t]{2}{*}{2009} & Andosol & 7.0 & 131.4 & 40.8 & 297.2 \\
\hline & Ferralsol & $13.9^{*}$ & $337.0^{*}$ & $80.6^{*}$ & $827.7^{*}$ \\
\hline \multirow[t]{2}{*}{2010} & Andosol & 0.4 & 7.2 & 39.6 & 193.6 \\
\hline & Ferralsol & $4.4^{*}$ & $52.9^{*}$ & 53.7 & $373.7^{*}$ \\
\hline \multirow[t]{2}{*}{2011} & Andosol & 1.6 & 23.5 & 64.2 & 1365.9 \\
\hline & Ferralsol & $4.9^{*}$ & $154.1^{*}$ & $84.1^{*}$ & $1993.4^{*}$ \\
\hline
\end{tabular}

severity increased during crop development each year on both soils but was always more severe for plants grown on the Ferralsol (Fig. 1): $80.6 \%$ vs $40.8 \%$ in $2009,53.7 \%$ vs $39.6 \%$ in 2010 and $84.1 \%$ vs $64.2 \%$ in 2011, at the last scoring dates. AUDPC for panicle blast were significantly lower in the Andosol compared to the Ferralsol, each year (Table 1).

\subsection{Yield and yield components}

Each year, the lowest yield was measured on rice plants grown without fungicide on the Ferralsol (Table 2). The yields obtained from rice plants grown on Ferralsol and receiving fungicides were two to three times higher than the yields obtained in plots containing Ferralsol without fungicide. These differences can mainly be explained by differences in fertility (\% of full grains) and in grain filling (weight of 1000 full grains), i.e. yield components that are established relatively late (Table 2). No differences were observed between treatments for the number of panicles per square meter, spikelets per panicle, and dry straw weight, yield components that are established early.

Differences in yields between rice plants grown on the Andosol and the Ferralsol without fungicide were significant in 2009 and 2010. Yields ranged from 1.1 to 1.6 tons per ha on Ferralsol vs. 3.8 tons per ha on Andosol in 2009 and 2010. Differences in yield were explained by differences in grain filling but also by differences in plant growth (dry straw weight, number of panicles per $\mathrm{m}^{2}$ and number of spikelets per panicle). In 2011, very low yields were obtained from plants grown in Andosol compared to the two previous years. No significant difference in any yield component was observed between these two soils.

\subsection{Soil and plant mineral analysis}

Soil analysis (Table 3) confirmed that the imported soil was richer in organic carbon and nitrogen than the local soil. The imported soil had a less acid $\mathrm{pH}$ than the local soil and higher concentrations of total and available phosphorus. Total Si content in the imported soil was slightly lower than in the local soil, whereas available $\mathrm{Si}$ was much higher (46.3 vs. $0.8 \mathrm{mg} \mathrm{kg}^{-1}$ ).

In 2009 and 2011, mineral analyses were performed on flag leaves at the booting stage to compare plants growing on Ferralsol and Andosol (Table 4). Many differences were observed each year but no difference in $\mathrm{N}$ content. The significant differences concerned silicon (Si) and phosphorus (P) contents, which were higher in the Andosol, and manganese (Mn) content, which was lower in the Andosol, especially in 2009 ( $4.3 \% \mathrm{Si}$ in plants on Ferralsol vs $11.2 \%$ in plants on Andosol). Some statistical differences were observed for other elements too, either in 2009 or in 2011.

\section{Discussion}

In the present study, a highly susceptible cultivar of upland rice was grown on two different soils at the same location for three years in a row, using identical traditional cropping practices with mineral fertilization. The differences in the severity of leaf blast were significant, but in our trials leaf blast levels were low (max $15 \%$ of leaf area affected by blast symptoms) and did not really affect plant growth in the early stages (number of panicles per $\mathrm{m}^{2}$, number of spikelets per panicle and dry straw weight were similar). On the other hand, panicle blast levels were high. On the Ferralsol, the blast epidemic was similar to the epidemics observed in previous years with $50 \%-80 \%$ of empty grains due to the disease. For the Andosol, the level of PB was reduced by $10 \%-50 \%$. The differences between the two soils had a direct effect on the yield components with a higher percentage of full grains and a higher full grain weight in plants grown on the Andosol. The associated increase in yield was $137-231 \%$ in the two first years but was not significant in the third year $(+36 \%)$. Differences were observed between years concerning the disease dynamics. This could be due to

Table 2

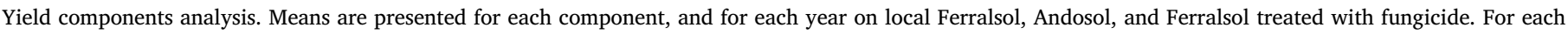

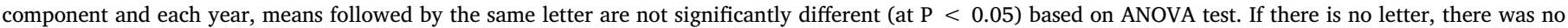
significant difference in the result between treatments.

\begin{tabular}{|c|c|c|c|c|c|c|c|}
\hline & & $\begin{array}{l}\text { Number of panicles } \\
\text { per } \mathrm{m}^{2}\end{array}$ & $\begin{array}{l}\text { Number of spikelets } \\
\text { per panicle }\end{array}$ & $\begin{array}{l}\text { Fertility (\% full } \\
\text { grains) }\end{array}$ & $\begin{array}{l}1000 \text { full grain weight } \\
\text { (g) }\end{array}$ & $\begin{array}{l}\text { Dry straw weight } \\
\text { (kg/ha) }\end{array}$ & Yield (kg/ha) \\
\hline \multirow[t]{3}{*}{2009} & Andosol & 422.1 & 67.2 & $57.2^{\mathrm{A}}$ & $23.7^{\mathrm{A}}$ & $5158^{\mathrm{A}}$ & $3788^{\mathrm{A}}$ \\
\hline & Ferralsol & 356.1 & 49.8 & $34.1^{\mathrm{B}}$ & $17.8^{\mathrm{B}}$ & $3566^{\mathrm{B}}$ & $1143^{\mathrm{B}}$ \\
\hline & Ferralsol + Fungicide & 348.8 & 62.2 & $57.8^{\mathrm{A}}$ & $24.5^{\mathrm{A}}$ & $3886^{\mathrm{B}}$ & $3061^{\mathrm{A}}$ \\
\hline \multirow[t]{3}{*}{2010} & Andosol & $516.4^{\mathrm{A}}$ & $75.0^{\mathrm{A}}$ & $41.7^{\mathrm{B}}$ & $24.0^{\mathrm{A}}$ & $10355^{\mathrm{A}}$ & $3774^{\text {B }}$ \\
\hline & Ferralsol & $409.7^{\mathrm{B}}$ & $56.9^{\mathrm{B}}$ & $36.3^{\mathrm{B}}$ & $19.9^{\mathrm{B}}$ & $6682^{\mathrm{B}}$ & $1591^{\mathrm{C}}$ \\
\hline & Ferralsol + Fungicide & $359.0^{\mathrm{B}}$ & $63.6^{\mathrm{AB}}$ & $78.3^{\mathrm{A}}$ & $27.2^{\mathrm{A}}$ & $5568^{\mathrm{B}}$ & $4842^{\mathrm{A}}$ \\
\hline \multirow[t]{3}{*}{2011} & Andosol & 477.3 & 55.9 & $19.5^{\mathrm{B}}$ & $19.7^{\mathrm{B}}$ & 5950 & $2090^{\mathrm{B}}$ \\
\hline & Ferralsol & 452.3 & 52.4 & $11.6^{\mathrm{B}}$ & $17.3^{\mathrm{B}}$ & 5617 & $1533^{\text {В }}$ \\
\hline & Ferralsol + Fungicide & 442.2 & 56.8 & $66.4^{\mathrm{A}}$ & $26.3^{\mathrm{A}}$ & 5419 & $4071^{\mathrm{A}}$ \\
\hline
\end{tabular}


Table 3

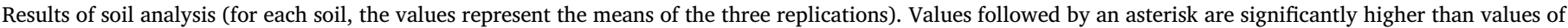
the same element in the other soil order $(\mathrm{P}<0.05)$.

\begin{tabular}{|c|c|c|c|c|c|c|c|c|c|}
\hline Soil & C (\%) & N (\%) & $\mathrm{pH}$ water & $\mathrm{pH} \mathrm{KCl}$ & $\mathrm{K} \mathrm{cmol. \textrm {kg } ^ { - 1 }}$ & P Olsen mg.kg ${ }^{-1}$ & $\mathrm{P}$ total $(\%)$ & Si total (mg.kg $\left.{ }^{-1}\right)$ & Available Si $\left(\mathrm{mg} \cdot \mathrm{kg}^{-1}\right)$ \\
\hline Ferralsol & 2.51 & 0.38 & 4.56 & 3.91 & $0.15^{*}$ & 3.53 & 0.051 & $79600 *$ & 0.8 \\
\hline Andosol & $4.35^{*}$ & $0.63^{*}$ & $5.67^{*}$ & $4.73^{*}$ & 0.07 & $17.50^{*}$ & $0.360^{*}$ & 34100 & $46.3^{*}$ \\
\hline
\end{tabular}

Table 4

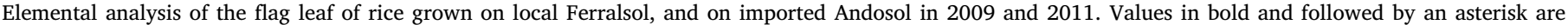
significantly higher than values of the same element in the other soil order, the same year (based on ANOVA test performed each year separately).

\begin{tabular}{|c|c|c|c|c|c|c|c|c|c|c|c|c|c|}
\hline Year & Soil & $\mathrm{SiO}_{2}(\%)$ & N (\%) & $\mathrm{P}(\%)$ & K (\%) & $\mathrm{Ca}(\%)$ & $\mathrm{Mg}(\%)$ & $\mathrm{Na}(\%)$ & S (\%) & $\mathrm{Cu}\left(\mathrm{mg} \cdot \mathrm{kg}^{-1}\right)$ & $\operatorname{Mn}\left(\mathrm{mg} \cdot \mathrm{kg}^{-1}\right)$ & $\mathrm{Zn}\left(\mathrm{mg} \cdot \mathrm{kg}^{-1}\right)$ & B (mg.kg $\left.{ }^{-1}\right)$ \\
\hline \multirow[t]{2}{*}{2009} & Ferralsol & 4.3 & 3.4 & 0.15 & $1.4^{*}$ & 0.48 & 0.18 & 0.016 & 0.19 & 9.2 & $1194 *$ & $13.6^{*}$ & 11.65 \\
\hline & Andosol & $11.2^{*}$ & 3.6 & $0.20 *$ & 1.2 & 0.50 & 0.24 & 0.016 & $0.22 *$ & 7.7 & 225 & 10.3 & $18.35^{*}$ \\
\hline \multirow[t]{2}{*}{2011} & Ferralsol & 4.3 & 3.7 & 0.17 & 1.4 & 0.24 & 0.14 & 0.011 & 0.23 & 9.4* & $761^{*}$ & 17.6 & 9.10 \\
\hline & Andosol & $5.9^{*}$ & 3.5 & $0.19 *$ & 1.3 & 0.23 & $0.18^{*}$ & $0.013^{*}$ & 0.23 & 6.5 & 97 & 18.5 & 8.35 \\
\hline
\end{tabular}

climatic conditions or to external factors influencing the date of apparition of the natural primary inoculum, and the beginning of epidemic development.

In previous experiments, we observed differences in blast severity with the cropping system (Sester et al., 2014; Dusserre et al., 2017) but the differences were systematically associated with a delay in development, which by itself, might help to explain the differences in the incidence and severity of blast. In the present study, plant growth was not only improved on the Andosol, even when compared with plants grown on Ferralsol and treated with fungicides, but blast severity was simultaneously lowered, resulting in a significant increase in yield. Our experiments thus confirm that soil order may influence significantly the epidemic development of blast disease in a rice crop whatever the climate, pathogen populations or other environmental factors.

In an attempt to identify the mineral elements which could be responsible for the reduced susceptibility of plants grown on the Andosol (Dordas, 2008), we analyzed the nutrient contents in flag leaves of rice growing on the Ferralsol and Andosol. Significant differences in silicon, phosphorus and manganese were measured each year (Table 4). No significant difference in nitrogen content was observed. Nitrogen is known to be associated with rice blast susceptibility (Ballini et al., 2013; Long et al., 2000; Pinnschmidt et al., 1995) but did not appear to be responsible for the differences in blast levels observed in the present study. According to physiological standards (CSIRO, 1997), the P content of the rice grown on the Ferralsol was probably deficient or at a critical level. The lower P content of the Ferralsol could reduce plant growth. Mn content appeared to be adequate or high. The role of elements in affecting rice blast susceptibility such as Mn or P are difficult to interpret; the literature is mixed in that these elements have been reported to either increase or decrease blast susceptibility (Datnoff et al., 2007; Cacique et al., 2012).

The silicon content in plants grown on the Ferralsol was below the Si threshold considered to be critical for plant growth (5\%) for leaves and straw (Dobermann and Fairhurst, 2000), as is often the case in subSaharan Africa (Tsujimoto et al., 2014). Silicon may well explain the differences in blast severity observed in the present study, as it has already been shown to have a highly significant impact on rice blast severity (Hayasaka et al., 2008; Ma and Yamaji, 2006; Nakata et al., 2008; Seebold et al., 2004). Correlations have been reported between the concentration of $\mathrm{Si}$ in rice plants and the amount of weatherable minerals in soils (Makabe et al., 2009). Poorly ordered aluminosilcates, such as allophane and imogolite, which are commonly found in volcanic soils and are easily weatherable (Churchman and Lowe, 2012), could be the source of silicon in the Andosol. Sources of silicon can be used to improve the level of plant-available $S i$ in the soil, but this would require imports of $\mathrm{Si}$ fertilizer, e.g. calcium silicate (Datnoff et al., 1997), or alternatively, the development of local production of Si fertilizer in Madagascar. Silicon can be supplied by plant-derived amorphous silica (phytoliths) present in plant residues, such as rice straw or manure amendments (Guntzer et al., 2012; Song et al., 2014; Pati et al., 2016; Haynes, 2017). Silicon availability may be improved by increasing soil $\mathrm{pH}$ (dolomite $\mathrm{CaMg}\left(\mathrm{CO}_{3}\right)_{2}$ can be easily found in Madagascar), by increasing soil biodiversity and using cropping practices that favor earthworms activity (Bityutskii et al., 2016).

The way silicon may influence plant-pathogen interactions is detailed in Wang et al. (2017) as a combination of four mechanisms: structural reinforcement, stimulation of systemic acquired resistance, production of antimicrobial compounds and activation of defense gene expression. In 2005, Qin and Tian proposed that silicon may act indirectly by an improvement of the effect of plant growth promoting rhizobacteria (PGPR). Some PGPR have been reported to induce resistance to rice blast (Filippi et al., 2011; Lucas et al., 2009; Spence et al., 2014).

The results of our study clearly demonstrate that rice blast development will vary for plants grown in different soil orders (Ferrasol vs Andosol). This variation in disease development is apparently due to the ability of the soil to provide sufficient levels of plant available silicon. Rice cropping systems should thus be adapted to improve soil Si levels, especially for those soils known to be low or limiting in this element, to enhance plant resistance to blast and subsequently improve plant yield and quality.

\section{Acknowledgements}

We are grateful to Victor Michel for his technical support and his efficient management of the field experiments and to Fidiniaina Ramahandry and Narcisse Moussa for their help with obtaining and transporting the Andosol. Many thanks to Dr. Régis Goebel for his help with the manuscript. This study was partially funded by the Groupement Semis Direct Madagascar (GSDM).

\section{References}

Ballini, E., Nguyen, T., Morel, J.-B., 2013. Diversity and genetics of nitrogen-induced susceptibility to the blast fungus in rice and wheat. Rice 6,32 .

Bastiaans, L., 1991. Ratio between virtual and visual lesion size as a measure to describe reduction on leaf photosynthésis of rice due to leaf blast. Phytopathology 81 , 611-615.

Bityutskii, N., Kaidun, P., Yakkonen, K., 2016. Earthworms can increase mobility and bioavailability of silicon in soil. Soil Biol. Biochem. 99, 47-53.

Bonman, J., 1992. Durable resistance to rice blast disease-environmental influences. 
Euphytica 63, 115-123.

Cacique, I.S., Domiciano, G.P., Rodrigues, F.Á., do Vale, F.X.R., 2012. Silicon and manganese on rice resistance to blast. Bragantia 71, 239-244.

Churchman, G.J., Lowe, D.J., 2012. Alteration, formation, and occurrence of minerals in soils. In: Huang, P.M., Li, Y., Sumner, M.E. (Eds.), Handbook of Soil Sciences, Vol 1, 2nd Edn, Properties and Processes. CRC Press, Boca Raton, pp. 20 1-20.72E (eds).

Cornelis, J.-T., Titeux, H., Ranger, J., Delvaux, B., 2011. Identification and distribution of the readily soluble silicon pool in a temperate forest soil below three distinct tree species. Plant Soil 342, 369-378.

Commonwealth Scientific and Industrial Research Organisation, 1997. In: Reuter, D.J., Robinson, J.B. (Eds.), Plant Analysis: an Interpretation Manual. CSIRO Publishing, Collingwood, Australia.

Datnoff, L.E., Deren, C.W., Snyder, G.H., 1997. Silicon fertilization for disease management of rice in Florida. Crop Protect. 16, 525-531.

Datnoff, L.E., Elmer, W.H., Huber, D.M. (Eds.), 2007. Mineral Nutrition and Plant Disease. American Phytopathological Society (APS Press).

Dobermann, A., Fairhurst, T., 2000. Rice: Nutrient Disorders \& Nutrient Management. (PPI, PPIC and IRRI Eds).

Dordas, C., 2008. Role of nutrients in controlling plant diseases in sustainable agriculture. A review. Agron. Sustain. Dev. 28, 33-46.

Dusserre, J., Chopart, J.L., Douzet, J., Rakotoarisoa, J., Scopel, E., 2012. Upland rice production under conservation agriculture cropping systems in cold conditions of tropical highlands. Field Crop. Res. 138, 33-41.

Dusserre, J., Raveloson, H., Michellon, R., Gozé, E., Auzoux, S., Sester, M., 2017. Conservation agriculture cropping systems reduce blast disease in upland rice by affecting plant nitrogen nutrition. Field Crop. Res. 204, 208-221.

FAOSTAT database, 2018. Available at http://faostat.fao.org/.

Filippi, M.C.C., da Silva, G.B., Silva-Lobo, V.L., Côrtes, M.V.C.B., Moraes, A.J.G., Prabhu, A.S., 2011. Leaf blast (Magnaporthe oryzae) suppression and growth promotion by rhizobacteria on aerobic rice in Brazil. Biol. Contr. 58, 160-166.

Guntzer, F., Keller, C., Poulton, P.R., McGrath, S.P., Meunier, J.-D., 2012. Long-term removal of wheat straw decreases soil amorphous silica at Broadbalk, Rothamsted. Plant Soil 352, 173-184.

Hayasaka, T., Fujii, H., Ishiguro, K., 2008. The role of silicon in preventing appressorial penetration by the rice blast fungus. Phytopathology 98, 1038-1044.

Haynes, R.J., 2017. The nature of biogenic Si and its potential role in Si supply in agricultural Soils. Agric. Ecosyst. Environ. 245, 100-111.

Horwitz, 1960. AOAC Washington Official Methods of Analysis of the Association of Official Agricultural Chemists, fourth ed. pp. 73.

IUSS Working Group WRB, 2014. World Reference Base for Soil Resources. International Soil Classification System for Naming Soils and Creating Legends for Soil Maps. World Soil Resources Reports, No 106. FAO, Rome.

Long, D., Lee, F.N., TeBeest, D.O., 2000. Effect of nitrogen fertilization on disease progress of rice blast on susceptible and resistant cultivars. Plant Dis. 84, 403-409.

Lucas, J.A., Ramos Solano, B., Montes, F., Ojeda, J., Megias, M., Gutierrez Mañero, F.J., 2009. Use of two PGPR strains in the integrated management of blast disease in rice (Oryza sativa) in Southern Spain. Field Crop. Res. 114, 404-410.

Ma, J.F., Yamaji, N., 2006. Silicon uptake and accumulation in higher plants. Trends Plant Sci. 11, 392-397.

Makabe, S., Kakuda, K.I., Sasaki, Y., Ando, T., Fujii, H., Ando, H., 2009. Relationship between mineral composition or soil texture and available silicon in alluvial paddy soils on the Shounai Plain, Japan. Soil Sci. Plant Nutr. 55, 300-308.

Nakata, Y., Ueno, M., Kihara, J., Ichii, M., Taketa, S., Arase, S., 2008. Rice blast disease and susceptibility to pests in a silicon uptake-deficient mutant lsi1 of rice. Crop Protect. 27, 865-868.

Ou, S.H., 1985. Rice Diseases, second ed. IRRI, Kew, UK.

Pati, S., Pal, B., Badole, S., Hazra, G.C., Mandal, B., 2016. Effect of silicon fertilization on growth, yield, and nutrient uptake of rice. Commun. Soil Sci. Plant Anal. 47, 284-290.

Pennisi, E., 2010. Armed and dangerous. Science 327, 804-805.

Pinnschmidt, H.O., Batchelor, W.D., Teng, P.S., 1995. Simulation of multiple species pest damage in rice using CERES-rice. Agr. Syst. 48, 193-222.

Qin, G.Z., Tian, S.P., 2005. Enhancement of biocontrol activity of cryptococcus laurentii by silicon and the possible mechanisms involved. Phytopathology 95, 69-75.

Raboin, L.-M., Ramanantsoanirina, A., Dzido, J.-L., Frouin, J., Radanielina, T., Tharreau, D., Dusserre, J., Ahmadi, N., 2013. Upland rice varieties for the highlands of Madagascar: review of a 25-year-long breeding program. Cah. Agric. 22, 450-458.

Raboin, L.-M., Randriambololona, T., Radanielina, T., Ramanantsoanirina, A., Ahmadi, N., Dusserre, J., 2014. Upland rice varieties for smallholder farming in the cold conditions in Madagascar's tropical highlands. Field Crop. Res. 169, 11-20.

Raunet, M., 1981. Le milieu physique de la région volcanique Ankaratra-VakinankaratraItasy. Aptitudes à la culture du blé pluvial. IRAT, Montpellier.

Raveloson, H., Ratsimiala Ramonta, I., Tharreau, D., Sester, M., 2018. Long-term survival of blast pathogen in infected rice residues as major source of primary inoculum in high altitude upland ecology. Plant Pathol. 67, 610-618.

Razafimbelo, T.M., Albrecht, A., Basile, I., Borschneck, D., Bourgeon, G., Feller, C., Ferrer, H., Michellon, R., Moussa, N., Muller, B., Oliver, R., Razanamparany, C., Seguy, L., Swarc, M., 2006. Effet de différents systèmes de culture à couverture végétale sur le stockage du carbone dans un sol argileux des Hautes Terres de Madagascar. Etud. Gest. Sols 13, 113-127.

Seebold, K.W., Datnoff, L.E., Correa-Victoria, F., Kucharek, T.A., Snyder, G.H., 2004. Effects of silicon and fungicides on the control of leaf and neck blast in upland rice. Plant Dis. 88, 253-258.

Seguy, L., Notteghem, J., Bouzinac, S., 1981. Etude des interactions sol-varietes de rizpyriculariose dans l'Ouest du Cameroun. In: Comptes rendus du Symposium sur la résistance du riz à la pyriculariose. Montpellier, France, pp. 138-152.

Sester, M., Raveloson, H., Tharreau, D., Dusserre, J., 2014. Conservation agriculture cropping system to limit blast disease in upland rainfed rice. Plant Pathol. 63, 373-381.

Song, Z., Wang, H., Strong, P.J., Shan, S., 2014. Increase of available soil silicon by Si-rich manure for sustainable rice production. Agron. Sust. Dev. 34, 813-819.

Spence, C., Alff, E., Johnson, C., Ramos, C., Donofrio, N., Sundaresan, V., Bais, H., 2014. Natural rice rhizospheric microbes suppress rice blast infections. BMC Plant Biol. 14, 130.

Tsujimoto, Y., Muranaka, S., Saito, K., Asai, H., 2014. Limited Si-nutrient status of rice plants in relation to plant-available Si of soils, nitrogen fertilizer application, and rice-growing environments across Sub-Saharan Africa. Field Crop. Res. 155, 1-9.

Wang, M., Gao, L., Dong, S., Sun, Y., Shen, Q., Guo, S., 2017. Role of silicon on plant-pathogen interactions. Front. Plant Sci. 8, 1-14. 